\title{
PENGARUH PELAKSANAAN AUDIT INTERNAL TERHADAP TINGKAT GOOD UNIVERSITY GOVERNANCE DENGAN KOMITMEN ORGANISASIONAL SEBAGAI VARIABEL MODERASI (Survey pada Perguruan Tinggi di Kota Bandung)
}

\author{
Herny Nurhayati
}

\begin{abstract}
ABSTRAK :
Penelitian ini dimaksudkan untuk menjawab masalah penelitian sebagai berikut : (a) apakah pelaksanaan audit internal secara langsung berpengaruh positif terhadap tingkat good university governance, dan (b) apakah komitmen organisasional berpengaruh positif dan memperkuat hubungan antara pelaksanaan audit internal dengan tingkat good university governance.

Yang menjadi unit analisis adalah perguruan tinggi di kota Bandung. Respondennya adalah audit internal, Pimpinan PT, dekan dan kepala biro. Populasinya adalah seluruh PT berjumlah 122. Pengujian hipotesis pertama menggunakan analisis regresi linier sederhana, sedangkan pengujian hipotesis kedua menggunakan analisis regresi linear berganda.

Hasil penelitian ini adalah : (a) pelaksanaan audit internal berpengaruh positif terhadap tingkat good university governance dan (b) komitmen organisasional memoderasi pengaruh pelaksanaan audit internal internal terhadap tingkat good university governance.

Kata kunci : Pelaksanaan Audit Internal, Komitmen Organisasional, Tingkat Good University Governance
\end{abstract}




\section{PENDAHULUAN}

Pemerataan akses dan peningkatan mutu pendidikan membuat warga negara Indonesia memiliki kecakapan hidup (life skills) sehingga mendorong tegaknya pembangunan manusia seutuhnya serta masyarakat madani dan modern yang dijiwai nilai - nilai Pancasila, sebagaimana yang telah diamanatkan dalam UU No 20 Tahun 2003 tentang Sistem Pendidikan Nasional (Renstra Kemendiknas 20102014).

Masalah yang dihadapi di dunia pendidikan diantaranya kondisi keuangan negara yang terbatas maka dibutuhkan peran masyarakat untuk membantu negara menyelenggarakan pendidikan yang dikelola oleh swasta (Sylviana Murni,2009).

lin Sunarti (2008) menyatakan manajemen pendidikan tinggi akan selalu mengacu pada peningkatan kualitas yang berkelanjutan (continues improvement) namun secara sosiologi saat ini konteks pendidikan tinggi negeri yang berstatus PTN seakan-akan mengarah kepada perlombaan untuk menaikan "tarif" biaya kuliah. Hal ini sesuai dengan pernyataan Bambang Triatmodjo (http://edukasi.kompas.com/read/2013/02/ 20/1521594/Uang.Kuliah.Tunggal) bahwa Data BPS tahun 2011 menunjukkan, jumlah penduduk usia 19-24 tahun (usia seseorang menempuh pendidikan tinggi) sekitar 24 juta jiwa. Kemiskinan dan tingginya biaya pendidikan menyebabkan tingkat pendidikan warga miskin rendah, prestasi akademik kurang baik, sehingga sulit untuk mendapatkan pekerjaan layak.

Dalam kajian riset Welch (2012) dalam Isnaini Nurhayati (2013) terdapat beberapa hal penting yang menjadi penghambat efektifitas perguruan tinggi di Indonesia yang diantaranya adalah pertumbuhan jumlah perguruan tinggi di Indonesia mengalami peningkatan setiap tahunnya, akan tetapi pertumbuhan tersebut tidak diikuti dengan peningkatan kualifikasi akademik serta rendahnya remunerasi yang diterima staf pengajarnya. Kondisi ini mendorong kualitas perguruan tinggi di Indonesia menjadi rendah.

Menurut Rosmita Dewi YR, R. Nelly Nur Apandi : 2012 dalam penelitiannya menunjukkan bahwa potensi fraud pada universitas terjadi karena lemahnya internal kontrol dan sistem akuntansi pada proses budgeting dan penundaan funding, kurangnya review dari top management. Beberapa tindakan fraud di perguruan tinggi terjadi karena lemahnya pengendalian internal diantarnya banyak terjadi penyelewengan penggunaan dana bantuan yang diberikan pemerintah kepada perguruan tinggi.

(Sawyer, 2005) output dari pelaksanaan audit internal ini tidak hanya berupa rekomendasi untuk perbaikan sistem dan metode, tetapi juga meliputi tindakan-tindakan perbaikan yang memperkecil dan meniadakan kelemahankelemahan, kegagalan-kegagalan, dan infesiensi dari berbagai program yang telah direncanakan oleh organisasi perusahaan yang bersangkutan.

Adapun audit internal yang berkualitas menurut The Standar for The Profesional Practice of Internal Auditing dapat dilihat dari independensi dan objektifitas, kemampuan profesional, lingkup pekerjaan dan pelaksanaan pemeriksaan. Menurut Sukirman dan Maylia Pramono Sari (2012) Institusi perguruan tinggi memiliki keistimewaan dibanding institusi lain yaitu terletak pada fungsi dasarnya, yaitu dalam hal pendidikan, pengajaran dan usaha penemuan atau inovasi (riset).

Organization For Economic Cooporation And Development (OECD : 2008) mengedepankan unsur penting dalam good university governance yaitu :

(transparancy),

(accountability),

(independence),

(responsibility)

(fairness). Prinsip-prinsip ini diperlukan di perguruan tinggi untuk mencapai kinerja yang berkesinambungan.

Menurut John Fielden : 2008, terdapat tiga negara yang menjadi pelopor atau pemimpin dalam melaksanakan good university governance, yaitu Australia, Denmark dan Inggris. Otonomi perguruan tinggi berpengaruh secara positif terhadap output perguruan tinggi, governance di perguruan tinggi (otonomi) dan kinerja perguruan tinggi, yang menunjukan bahwa output perguruan tinggi yang baik dipengaruhi oleh otonomi perguruan tinggi itu sendiri. Hal ini sejalan dengan pengukuran good university governance di Indonesia, yang mengacu pada pemenuhan 15 standar yang dikeluarkan oleh Badan Akreditasi Nasional perguruan Tinggi 2009 (BAN-PT).

Harapan jangka panjang dari konsep good university governance dalam penyelenggaraan perguruan tinggi adalah masyarakat kampus mampu tergerak untuk berusaha lebih memahami dan ikut kritis dalam memberikan masukan-masukan 
menuju penyelenggaraan perguruan tinggi yang lebih baik. (Swanson, 2005). Komitmen organisasional mencerminkan bagaimana seorang individu mengidentifikasikan dirinya dengan organisasi dan terkait dengan tujuantujuannya Jerald Greenberg (2003:160). pengukuanr komponen komitmen organisasional menggunakan 3 jenis komponen yaitu :Continuance commitment, Affective commitment, Normative commitment.

Fred Luthans (2005:217) mendefinisikan komitmen organisasi sebagai : (1) suatu keinginan yang kuat untuk tetap menjadi anggota organisasi, (2) kesediaan untuk berusaha sebaik mungkin untuk kepentingan organisasi, dan (3) kepercayaan dan penerimaan yang kuat terhadap nilai-nilai dan tujuan organisasi, Terdapat tiga dimensi dalam komitmen organisasional yaitu : Komitmen afektif (affektive commitment), komitmen kontinyu (continuance commitment), dan komitmen normatif (normative commitment).

Penelitian ini bertujuan untuk menggali sejauh mana good university governance pada organisasi pendidikan,menghasilkan output yang berkualitas maka diperlukan kerjasama dan keterlibatan langsung antara pelaksanaan audit internal dan komitmen organisasional.

\section{Rumusan Masalah}

Apakah pelaksanaan audit internal secara langsung berpengaruh positif terhadap tingkat good university governance dan Apakah komitmen organisasional berpengaruh positif dan memperkuat hubungan antara pelaksanaan audit internal dengan tingkat good university governance pada Perguruan Tinggi di Kota Bandung.

\section{Tujuan Penelitian}

Untuk mengetahui pengaruh pelaksanaan audit internal terhadap tingkat good university governance dan untuk mengetahui pengaruh komitmen organisasional terhadap peningkatan hubungan antara pelaksanaan audit dengan tingkat good university governance pada Perguruan Tinggi di Kota Bandung.

\section{METODE}

Metode penelitian yang digunakan explanatory research. Penelitian ini tergolong cross sectional studies, variabel yang akan digunakan yaitu variabel bebas (independent variable) yaitu pelaksanaan audit internal (X1), variabel komitmen organisasional (X2) sebagai variabel moderasi dan variabel terikat (dependent variable) yaitu tingkat good university governance $(\mathrm{Y})$.

Unit analisis dalam penelitian ini Perguruan Tinggi yang berada di kota Bandung dan terdaftar pada Direktori Dikti 2013. Jumlah populasi 122 perguruan tinggi dengan tingkat kesalahan 5\%, maka jumlah sampelnya dibulatkan menjadi 94.

Teknik sampel yang digunakan Proportional Random Sampling. Responden dalam penelitian terdiri dari Auditor internal/SPI, dewan pengawas, Majelis Wali Amanat (MWA) perguruan tinggi untuk mengukur variabel pelaksanaan audit internal alasannya adalah pada pemahaman akan pelaksanaan audit internal di perguruan tinggi serta menetapkan kebijakan audit internal. Sementara pimpinan perguruan tinggi, rektor, dekan, kepala biro selaku penanggung jawab perguruan tinggi secara umum memiliki tugas untuk menilai dan melaporkan hasil kerja perguruan tinggi kepada para stakeholdersnya, sebagai responden pengukuran terhadap komitmen organisasional dan tingkat good university governance.

Metode pengumpulan data adalah kuesioner (angket). Jenis data berupa data primer, Jenis angket yang digunakan angket tertutup (close form questioner).

Perhitungan uji validitas menggunakan bantuan program SPSS for windows versi 20.00 memudahkan peneliti.

Uji reliabilitas dilakukan dengan menggunakan teknik belah dua (split half) dengan rumus Spearman Brown.

Pengukuran variabel pada penelitian ini menggunakan skala likert. Data yang diperoleh dari jawaban kuesioner adalah data skala ordinal. Yang kemudian diubah menjadi skala data interval menggunakan method of successive interval (MSI).

Alat statistik yang digunakan teknik analisis regresi. Dalam model analisis regresi terdapat asumsi-asumsi yang harus dipenuhi:

1. Uji normalitas (kolmogorov smirnov test)

2. Asumsi Multikolinearitas

3. Asumsi Heteroskedastis.

Terdapat dua hipotesis dalam penelitian ini, yaitu :

Hipotesis pertama diuji dengan menggunakan analisis regresi linear 
sederhana (simple linear regression). Hipotesisnya adalah:

$\mathrm{H} 1$ : Pelaksanaan audit internal berpengaruh positif terhadap Good University Governance pada Perguruan Tinggi di kota Bandung. Hipotesis kedua diuji dengan menggunakan multiple linear regression analysis (uji nilai selisih mutlak). Hipotesisnya adalah:

H2 : Komitmen organisional berpengaruh terhadap hubungan antara pelaksanaan audit internal dan tingkat good university governance.

Dalam menguji hipotesis kedua ini tidak menggunakan uji interaksi (moderated regression analysis) sebagaimana yang umum digunakan untuk menguji pengaruh suatu variabel moderasi, hal ini disebabkan karena regresi dengan variabel interaksi, umumnya menimbulkan masalah oleh karena itu akan terjadi multikolinearitas yang persamaan regresi tersebut diatas dilakukan dengan menggunakan bantuan perangkat lunak (software) SPSS versi 20.0

Penafsiran dari setiap output akan memberikan informasi apakah hipotesis penelitian diterima atau ditolak. Penjelasan dari setiap item penilaian adalah sebagai berikut : (1)Pengujian Koefisien Determinasi (koefisien $\mathrm{R}^{2}$ ), (2)Pengujian Koefisien Regresi (koefisien b), (3) Pengujian signifikansi simultan (uji statistik F) atau Anova (analisys of variance), (4)Pengujian signifikansi parameter individual.

\section{HASIL PEMBAHASAN}

Dengan menggunakan asumsi bahwa objek penelitian merupakan variabel yang homogen di tingkat perguruan tinggi, maka data hasil penelitian yang didapatkan dari satu orang responden diputuskan untuk dapat mewakili perguruan tinggi.

Jumlah kuesioner yang disebarkan adalah 9 set dibagikan ke 122 perguruan tinggi di kota Bandung. Kuesioner yang diterima 849 dari kuesioner yang dikirim sebanyak 9 set dari 122 PT, maka respon rate nya (per reponden) adalah $81,97 \%$.

Adapun kuesioner yang diterima untuk masing masing variabel adalah Untuk responden variabel pelaksanaan audit internal ada 273 dari kuesioner yang dikirim sebanyak 366, maka respon rate nya (per reponden) adalah 74,59\%, untuk responden variabel komitmen organisasional ada 288 dari kuesioner yang dikirim sebanyak 366, maka respon rate nya (per reponden) adalah 78,69\% dan untuk responden variabel Tingkat good university governance ada 288 dari kuesioner yang dikirim sebanyak 366, maka respon rate nya (per reponden) adalah $78,69 \%$.

\section{Pengujian Validitas Instrumen}

Untuk menguji validitas instrumen penelitian digunakan teknik korelasi product moment dari pearson. Instrumen yang digunakan untuk mengukur variabel pelaksanaan audit internal adalah mengacu pada standar profesi audit internal bagian standar kinerja yang dikeluarkan oleh IIA 2004 yaitu terdiri dari 15 (lima belas) butir pertanyaan. Untuk mengukur variabel komitmen organisasional adalah instrumen yang dikembangkan oleh Fred Luthans (2005:218) yaitu terdiri dari 13 butir pertanyaan. Untuk mengukur variabel tingkat good university governance adalah mengacu pada Standar Akreditasi (BANPT,2009) dan James A. Swanson (2005) yang terdiri dari 25 butir pertanyaan. Dari hasil pengolahan data maka dihasilkan harga koefisien korelasi antara skor butir pertanyaan suatu instrumen lebih besar dari 0,30 maka dinyatakan valid.

\section{Pengujian Reliabilitas Instrumen}

Untuk menguji reliabilitas instrumen penelitian ini dilakukan teknik belah dua (split half) yang dianalisis dengan rumus Spearman Brown. Dihasilkan untuk Pelaksanaan Audit Internal harga koefisien reliability yang didapatkan lebih besar dari 0,70 (yaitu 0,917). Untuk Komitmen Organisasional harga koefisien reliability yang didapatkan lebih besar dari 0,70 yaitu $(0,970)$, Untuk Tingkat Good University Governance. harga koefisien reliabilitas yang didapatkan lebih besar dari 0.70 (yaitu 0,954).

\section{Hasil Pengujian Asumsi Klasik}

Dalam penelitian ini terdapat 2 model yang digunakan untuk menguji hipotesis. Model pertama, untuk menguji hipotesis satu, menggunakan persamaan regresi linier sederhana dan model kedua, untuk menguji hipotesis dua menggunakan regresi linier berganda.

\section{Uji Normalitas}

Hasilnya tampak bahwa plotting data residual menyebar disekitar garis diagonal dan mengikuti pola distribusi normal, sehingga model regresi 1 dapat dinyatakan memenuhi asumsi normalitas. 
Pada grafik normal probability plot untuk model regresi 2 tampak bahwa plotting data residual menyebar disekitas garis diagonal dan mengikuti pola distribusi normal, sehingga model regresi 2 dapat dinyatakan memenuhi asumsi normalitas.

Metode analisis statistik yang digunakan uji statistik Kolmogorov Smirnov (K-S). tingkat alpha yang ditetapkan sebesar 0.05. Hasil dari one-sample Kolmogorov smirnov test hasil uji normalitas analisis statistik untuk model regresi 1 : tampak bahwa nilai asymp.sig (2tailed) lebih besar dari tingkat alpha 0,05 (yaitu 0,844), sehingga dengan diterimanya H0 maka model regresi 1 dapat dinyatakan memenuhi asumsi normalitas. Model regresi 2 tampak bahwa nilai asymp.sig (2tailed) lebih besar dari tingkat alpha 0,05 (yaitu 0,668 ), sehingga dengan diterimanya H0 maka model regresi 2 dapat dinyatakan memenuhi asumsi normalitas.

\section{Uji Multikolinearitas}

Karena model regresi 1 hanya terdapat satu variabel independen maka uji multikolinearitas hanya dilakukan terhadap model regresi 2 saja. hasil uji multikolinearitas untuk model regresi 2 : tampak bahwa semua nilai toleransi tidak ada yang kurang dari 0,05 (yaitu 0,973 ; 0,$768 ; 0,770$ ) dan semua nilai VIF tidak ada yang lebih dari 10 (yaitu 1,028; 1,303; $1,299)$, sehingga dapat dinyatakan bahwa tidak ada multikolinearitas antar variabel bebas (independen) dalam model regresi 2.

\section{Uji Heteroskendastisitas}

Output SPSS grafik scatter plot hasil uji heteroskendastisitas untuk model regresi 1 : nampak bahwa titik-titik menyebar secara acak serta tersebar baik diatas maupun dibawah angka 0 sumbu $Y$, sehingga dapat disimpulkan bahwa tidak terjadi heteroskendastisitas pada model regresi 1. Sedangkan pada Grafik scatter plot yang dihasilkan SPSS untuk model regresi 2 tampak bahwa titik-titik menyebar secara acak serta tersebar baik diatas maupun dibawah angka 0 sumbu $\mathrm{Y}$, sehingga dapat disimpulkan tidak terjadi heteroskedastisitas pada model regresi 2 .

Metode analisis statistik yang digunakan uji glejser. pengujian heteroskendastisitas untuk model regresi 1 : tampak nilai Sig. untuk variabel independen lebih besar dari tingkat alpha 0,05 (Yaitu 0,106), sehingga dapat disimpulkan tidak terjadi heteroskendastisitas pada model regresi 1. uji glejser yang dihasilkan SPSS untuk model regresi 2 tampak bahwa nilai Sig. untuk semua variabel independen lebih besar dari tingkat alpha 0.05 (yaitu 0,121 $; 0,157 ; 0,074$ ), sehingga dapat disimpulkan tidak terjadi heteroskendastisitas pada model regresi 2 .

\section{Hasil Pengujian Hipotesis}

Untuk menguji hipotesis pertama, digunakan uji regresi sederhana (analisis regresi linier sederhana) hasil pengujian hipotesis persamaan regresi pertama : pada model summary, koefisien determinasi $\mathrm{R}$ (Square) adalah 0,481. Sehingga dapat dinyatakan bahwa kemampuan model regresi 1 untuk menjelaskan variasi variabel dependen tingkat good university governance (YGUG) dengan variabel independen pelaksanaan audit internal (XAI) sebesar 48,1\%, selebihnya dijelaskan oleh sebab-sebab lain yang tidak terdapat dalam model regresi 1.

Hasil pada coefficients, besarnya koefisien regresi (b) adalah $+0,694$. Hal tersebut menerangkan bahwa setiap kenaikan 1 (satu) poit pada variabel indepanden pelaksanaan audit internal (XAI) akan menyebabkan kenaikan sebesar 0,694 point pada variabel dependen tingkat good university governance (YGUG). Sehingga dapat dinyatakan variabel tingkat good university governance (YGUG) pada coeffiecients, besarnya signifikansi yang didapatkan $(0,000)$ lebih kecil dari tingkat signifikansi yang ditetapkan yaitu sebesar 0,05 maka dapat dinyatakan variabel pelaksanaan audit internal (XAl) secara individual mempengaruhi variabel tingkat good university governance (YGUG).

Dijelaskan bahwa hasil pengujian hipotesis pertama dengan menggunakan model regresi 1 menyatakan variabel pelaksanaan audit internal (XAl) berpengaruh positif terhadap variabel tingkat good university governance (YGUG). Sehingga dapat disimpulkan bahwa hipotesis pertama diterima.

Untuk menguji hipotesis kedua digunakan uji nilai selisih mutlak (analisis regresi linear ganda) output SPSS hasil pengujian hipotesis persamaan regresi kedua : pada model summary, besarnya koefisien determinasi ( $R$ square) adalah 0,520 ). Sehingga dapat dinyatakan kemampuan model regresi 2 untuk menjelaskan variabel independen pelaksanaan audit internal (XAl) dan variabel moderat komitmen organisasi 
(XKO) adalah sebesar $52,0 \%$, selebihnya dijelaskan oleh sebab-sebab lain yang tidak terdapat dalam model regresi 2 .

Pada Coefficients, besarnya koefisien regresi (b1) adalah $+0,724$. Hal tersebut menerangkan bahwa setiap kenaikan 1 (satu) point pada variabel independen pelaksanaan audit internal (XAI), akan menyebabkan kenaikan sebesar 0,724 point pada variabel dependen tingkat good university governance (YGUG). Sehingga dapat dinyatakan bahwa variabel pelaksanaan audit internal (XAI) berpengaruh positif terhadap variabel tingkat good university governance (YGUG).

Besarnya koefisien regresi (b2) adalah $+0,140$. Hal tersebut menerangkan setiap kenaikan 1(satu) point pada variabel independen komitmen organisasi (XKO), akan menyebabkan kenaikan sebesar 0,140 poin pada variabel dependen tingkat good university governance (YGUG). Sehingga dapat dinyatakan variabel komitmen organisasional (ZKO) berpengaruh positif terhadap variabel tingkat good university governance (YGUG).

Dari tabel diatas pada coeffisiens, besarnya koefisien regresi (b3) adalah $+0,245$. Hal tersebut menerangkan bahwa setiap kenaikan 1(satu) point selisih antara variabel independen pelaksanaan audit internal (XAI) dan variabel moderat komitmen organisasional (XKO), akan menyebabkan kenaikan sebesar 0,245 poin pada variabel dependen tingkat good university governance (YGUG).

Pada uji ANOVA, besarnya signifikansi (Sig.) adalah 0,000. Hal tersebut dapat diterangkan bahwa karena signifikansi yang didapatkan lebih kecil dari tingkat signifikansi yang ditetapkan yaitu 0,05 , maka dapat dinyatakan variabel pelaksanaan audit internal (XAl) dan variabel komitmen organisasional (XKO) secara bersama-sama mempengaruhi variabel tingkat good university governance (YGUG).

Pada coefficients, besarnya signifikansi individual (Sig.) untuk variabel independen pelaksanaan audit internal (XAl) adalah 0,000 . Hal tersebut dapat diterangkan bahwa karena nilai signifikasi yang didapatkan lebih kecil dari tingkat signifikansi yang ditetapkan yaitu 0,05 ,maka dapat dinyatakan variabel pelaksanaan audit internal (XAI) secara individual mempengaruhi variabel tingkat good university governance (YGUG).
Besarnya signifikansi parameter individual (Sig.) untuk variabel independen komitmen organisasi (XKO) adalah 0,096. Hal tersebut dapat diterangkan bahwa nilai signifikansi yang didapatkan lebih besar dari tingkat signifikansi yang ditetapkan yaitu 0,05 , maka dapat dinyatakan variabel komitmen organisasional (XKO) secara individual tidak mempengaruhi variabel tingkat good university governance (YGUG)

Besarnya signifikansi parameter individual (Sig) untuk variabel moderasi komitmen organisasional (XKO) adalah 0,009 . Hal tersebut dapat diterangkan bahwa nilai signifikansi yang didapatkan lebih kecil dari tingkat signifikansi yang ditetapkan yaitu $5 \%$ atau 0,05 , maka dapat dinyatakan variabel moderasi komitmen organisasional (ABS XAI-XKO) mempengaruhi variabel tingkat good university governance (YGUG).

\section{Pembahasan Hasil Pengujian Hipotesis}

Sebagai alat ujinya digunakan teknik analisis regresi. Pada anak subbab pengujian hipotesis pertama dijelaskan bahwa hasil pengujian hipotesis pertama menggunakan model regresi 1, menyatakan variabel pelaksanaan audit internal berpengaruh positif dan signifikan terhadap variabel tingkat good university governance. Sehingga dapat disimpulkan bahwa melalui pengujian hipotesis secara empiris maka hipotesis pertama diterima.

Peningkatan pelaksanaan audit internal akan meningkatkan tingkat good university governance. Pada kondisi seperti ini pelaksanaan audit internal yang dilakukan oleh para auditor internal sudah sesuai dengan standar kinerja pelaksanaan audit internal.

Disamping itu, koefisien determinasi (koefisien $\mathrm{R}^{2}$ ) yang dihasilkan adalah sebesar 0,481 atau $48,1 \%$. Ini menunjukan bahwa masih banyak faktor lain (sebesar $51,9 \%$ ) yang dapat mempengaruhi tingkat good university governance selain dari pelaksanaan audit internal. Beberapa variabel lain yang dianggap dapat mempengaruhi variabel dependen tingkat good university governance akan dijelaskan pada analisis hasil pengujian hipotesis kedua.

Pada anak subbab pengujian hipotesis kedua dijelaskan bahwa hasil pengujian hipotesis kedua menggunakan model regresi 2 menyatakan bahwa variabel komitmen organisasional memoderasi pengaruh variabel pelaksanaan audit internal terhadap 
variabel tingkat good university governance. Sehingga dapat disimpulkan bahwa setelah melalui pengujian hipotesis secara empiris maka hipotesis kedua diterima.

Koefisiean deretminasi (koefisien $R^{2}$ ) yang dihasilkan adalah sebesar 0,520 atau sebesar 52,0 \%. Ini menunjukan bahwa masih banyak faktor lain (sebesar $48,0 \%$ ) yang dapat mempengaruhi variasi tingkat good university goverlknance selain dari pelaksanaan audit internal yang dimoderasi komitmen organisasional. Koefisien determinasi yang dihasilkan model regresi 2 (sebesar 52,0\%) secara relative masih lebih tinggi dari koefisien determinasi yang dihasilkan model 1 (sebesar 48,1\%). Dengan demikian dapat dinyatakan bahwa model regresi 2 secara relative dapat menerangkan variasi tingkat good university governance dengan lebih baik dari pada model regresi 1.

Variabel komitmen organisasional, yang merupakan variabel individu, memiliki peranan yang efektif meskipun masih sangat kecil untuk menindaklanjuti hasil temuan atau rekomendasi auditor internal dalam kaitannya menciptakan tingkat good university governance. Hal tersebut disebabkan masih terdapat variabel lain, yang berdasarkan rendahnya koefisien determinasi yang diperoleh baik dari model regresi 1 maupun model regresi 2 yaitu masing-masing sebesar $48,1 \%$ dan $52,0 \%$ mengindikasikan adanya faktor lain yang berpotensi berperan cukup besar dalam menjelaskan variasi variabel dependen baru yang secara dominan berpengaruh terhadap variabel dependen tingkat good university governance, baik secara langsung (sebagai variabel independen) maupun tidak langsung (sebagai variabel moderasi).

Berdasarkan hasil pengujian hipotesis pertama dan kedua, yang menyatakan bahwa pelaksanaan audit internal sebagai variabel independen, kemudian komitmen organisasional sebagai variabel moderasi, pengaruhnya terhadap variabel dependen tingkat good university governance masih sangat rendah, maka penulis berpendapat bahwa masih terdapat variabel independen lain selain variabel komitmen organisasional yang baik secara langsung (sebagai variabel independen) maupun tidak langsung (sebagai variabel moderasi) berpengaruh terhadap terciptanya variabel tingkat good university governance (sebagai variabel dependen).

\section{SIMPULAN DAN SARAN \\ Simpulan}

1. Berdasarkan hasil pengujian hipotesis pertama dapat disimpulkan pelaksanaan audit internal di perguruan tinggi di kota Bandung berpengaruh positif terhadap tingkat good university governance.

2. Berdasarkan hasil pengujian hipotesis kedua dapat disimpulkan komitmen organisasi memoderasi pelaksanaan audit internal di perguruan tinggi di kota Bandung berpemgaruh terhadap tingkat good university governance.

\section{Saran}

1. Untuk meningkatkan good university governance, pihak manajemen perguruan tinggi hendaknya lebih mengefektifkan fungsi audit internal Pemberian wewenang dalam pengelolaan keuangan secara otonomi perlu ditingkatkan secara mandiri dan secara optimal sehingga diharapkan dapat mengembangkan dana abadi.

2. Agar lebih dapat membuktikan pelaksanaan audit internal terhadap tingkat good university governance, maka indikator variabel pelaksanaan audit internal tidak hanya dari standar kinerja profesi auditor internal tapi juga perlu ditambahkan indikator pelaksanan kode etik dan standar attribute profesi auditor internal.

3. Untuk menghasilkan model penelitian yang benar-benar dapat menjelaskan variasi variabel tingkat good university governance, maka perlu dilakukan penelitian pada seluruh perguruan tinggi agar diperoleh hasil yang lebih akurat.

\section{DAFTAR PUSTAKA}

Bambang Triatmodjo (http://edukasi.kompas.com/read/2 013/02/20/1521594/Uang.Kuliah.Tu nggal

Filden, J. 2008. Global Trend in University Governance. Education Working Paper Series, No.9. Word Bank, Washington

Greenberg Jerald, 2003. Behavior In Organizational. Eight Edition. 
Pearson Education, Inc. Upper Saddle. New Jersey.

Imam Ghazali. 2006. Aplikasi Analisis Multivariate dengan Program SPSS. Semarang: Badan Penerbit Universitas Diponegoro.

Institute of Internal Auditors, 2004. International Standars for the Professional Practice of Internal Auditing. The IIA Research Foundation, Maitland avenue Almonte Spring.

Isnaini Nurhayati 2013, Pengaruh Good University Governance, Efektifitas Audit Internal, Komitmen Organisaional Terhadap Kinerja Manajerial Dengan Partisipasi Pengganggaran Sebagai Variabel Intervening, Desertasi Universitas Padjadjaran Bandung 2013

James A Swansson, Karen E Mow And Staphen Bartos, 2005." Good University Governance In Australia", National Institute For Governance The University of Canberra. Refereed Proceedings Of 2005 Forum Of The Australasian Association For Institutional Research ISBN 0-646-45592-3

Kemendiknas,2010 Rencana Strategis Kementrian PendidikanNasional 2010-2014

Komite Nasional Kebijakan Governance, 2006 Pedoman Umum Good Corporate Govermance $\mathrm{Di}$ Indonesia.

Luthans, Fred. 2005. Organizational Behavior. Tenht Edition, McgrawHill. Companies Inc. America. New York.

Maylia Pramono Sari Dan Raharja. 2011 Peran Audit Internal Dalam Upaya Mewujudkan Good Corporate Governance (Gcg) Pada Badan Layanan Umum (Blu) Di Indonesia

OECD. 2008 Tertiary Education For The Knowladge Society. Vol.1, OECD, Paris

Rozmita Dewi YR, R. Nelly Nur Apandi, 2012. Gejala fraud dan peran auditor internal dalam pendeteksian fraud di lingkungan perguruan tinggi (studi kualitatif), Jurnal Universitas Pendidikan Indonesia, Bandung

Sawyer B. Lawrence., Mortiner A. Dittenhover., James H. Scheiner 2005, Sawyer, Internal Auditing, 5 Edition The Practise Of Modern Internal Auditing The Institute Ot Internal Auditor. Florida.
Sukirman Dan Maylia Pramono Sari, 2012 "Peran Internal Audit Dalam Upaya Mewujudkan Good University Governance Di UNNES", Jurnal Dinamika Akuntansi Vol.4, No. 1, Maret 2012, Pp.64-71.

Sunarti lin, 2008. Penerapan Total Quality Management in Education (TQME) Pada Perguruan Tinggi, Equilibrium Education Vol.4 No 8: 79-85.

Swansson, J.A., K.E Mow And S. Bartos. 2005. Good University Governance In Australia. Refereed Procesdings Of 2005 Forum Of The Australasian Association For Institutional Reseacrh, ISBN 0-646-45592-3, 98109

Sylviana Murni, 2009. "Manajemen Pendidikan Berbasis Elektronik (ELearning) Dalam Menyiapkan Sumber Daya Manusia Handal Menuju Terciptanya Clean And Good Governance", Jurnal Pendidikan Dan Kebudayaan, Vol. 15, Edisi Khusus II, 2009.

UU No 20 Tahun 2003 Tentang Sistem Pendidikan Nasional (Renstra Kemendiknas 2010-2014).

Welch, Anthony. "The limits of regionalism in Indonesian higher education." Asian Education and Development Studies 1.1 (2012): 24-42. 